І. І. Новаківський, А. Л.Висоцький ${ }^{1}$

Національний університет “Львівська політехніка”, кафедра менеджменту організацій,

${ }^{1}$ кафедра економіки підприємства та інвестицій

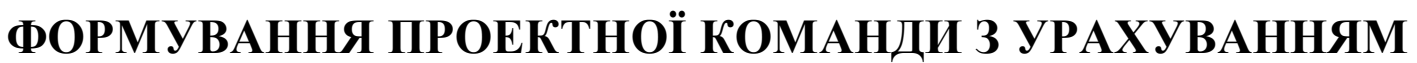 ТИПОЛОГІЧНИХ ХАРАКТЕРИСТИК МЕНЕДЖЕРІВ
}

https://doi.org/10.23939/semi2019.03.113

(С) Новаківський I. I., , Висоџький А. Л., 2019

У статті наведено підхід щодо формування ефективних управлінських команд 3 урахуванням комплексного розгляду завдань, які постають перед організацісю. Зокрема досліджено теоретичні основи вирішення прикладних проблем адаптації систем менеджменту $з$ урахуванням людського чинника. Представлено бачення управління організацією через тріаду теорія - політика - практика, розкрито сутність кожного вказаного елемента в менеджменті. Запропоновано типологічний підхід щодо оцінювання світогляду менеджерів 3 урахуванням такого підходу в спеціалізованому тривимірному просторі. Показано, що сукупність функцій кожного конкретного менеджера можна представити певним конусом типових рішень. Розроблено метод формування проектних команд з урахуванням конусу узагальнених функцій $\mathbf{i}$ характеристик менеджерів-претендентів. Порівняння експертних оцінок роботи менеджера дає змогу результативно формувати управлінські проектні команди для ефективного розвитку організації, розробити концепцію адаптації системи управління організації з урахуванням людського фактора.

Ключові слова: закони розвитку, економічна тріада, теорія, економічна політика, практика, управління, конус функціональних завдань, модель, задача математичного програмування.

\author{
I. Novakivskyi, A. Vysotskyi ${ }^{1}$ \\ Lviv Polytechnic National University, \\ Department of Management of Organizations \\ ${ }^{1}$ Departamet of Business Economics and Investment
}

\section{FORMING THE PROJECT TEAM WITH TYPOLOGICAL CHARACTERISTICS OF MANAGERS}

(C) Novakivsky I.., Visotskiy, A., 2019

The article presents the approach to the formation of effective management teams, taking into account the complex review of tasks that appear in front of the organization. The development of the modern economy marked the structural changes in which knowledge became the main driving force, and therefore the requirements for organizing managerial labour increased significantly. The path of scientific search for methods of building rational organizational structures lies in the plan of studying the human factor in the field of managerial decision making. In particular, the theoretical foundations of solving applied problems of adapting management systems taking into account the typological characteristics of specialists have been studied. In modern conditions, effective management is a set of purposeful actions regarding the formation of a team of managers aimed at implementing projects or a set of tasks in time under the influence of the external environment. The vision of managing an organization through a triad theory - policy - practice is presented, the essence of each specified element in management is revealed. Accordingly, an effective manager should 
be guided not only by economic knowledge, but should adhere to the policy of organizing the activities of the organization, possess management tools in practice. A typological approach is proposed with respect to evaluating the managers' worldview with regard to such an approach in a specialized three-dimensional space. It is shown that the set of functions of each specific manager can be represented by a certain cone of typical solutions. A method has been developed for the formation of project teams taking into account the cone of generalized functions and characteristics of the candidate managers. Unleashing such a task is raised to the problem of mathematical programming. It was confirmed that on the basis of close and precise interaction between the members of the management team and the active environment of the organization, an active field for making management decisions is formed. Comparison of expert assessments of the managerial work makes it possible to effectively form management project teams in accordance with prospective development of the organization. In its turn it allows to create the concept of adapting the management system of the organization, taking into account the human factor.

Key words: laws of development, economic triad, theory, economic policy, practice, management, cone of functional tasks, model, task of mathematical programming.

\section{Постановка проблеми}

Запровадження ефективних форм менеджменту, побудованих на наукових принципах, i сьогодні $є$ визначальним чинником успішного економічного розвитку організацій. Інтенсифікація науково-технічного прогресу призвела до динамічного і багатоваріантного застосування широкого спектру нових наукових підходів у менеджменті $[1,2,9]$. Водночас традиційний менеджмент досі великою мірою дотримується традицій централізованої типізації організаційних структурних побудов, жорсткої формалізації внутрішніх і зовнішніх відносин співпідпорядкованості, обмеження свобод підпорядкованих ланок, масове поширення і тривале використання апробованих часом організаційних схем, які придатні для заданих умов або надзвичайних обставин. Така ситуація у вітчизняних організаціях до поширення стереотипів консервативного мислення і типових організаційних шаблонів. Тепер постає завдання сформувати новий підхід щодо ефективного організування системи менеджменту у вітчизняних організаціях.

Аналіз останніх досліджень і публікацій

Теоретичні аспекти дослідження щодо адаптування систем управління організацій у сучасних умовах розглянуті у роботах багатьох вітчизняних і зарубіжних вчених. Серед них доцільно назвати таких відомих вчених, як: Р. Акофф, И. Ансофор, Р. Белбін, В. Богданов, В. Геєць, П. Дракер, В. Ільїн, М. Мескон, М. Разу, М. Ремізов, В. М. Палтерович, Й. Шумпетер та багато ін. В їхніх працях головна увага зосереджена на питаннях модернізації системи менеджменту, впровадженні нових наукових методів управління. Сьогодні організаційні структури управління стають дедалі гнучкішими, більш динамічними, адаптивними, що потребує детальнішого вивчення. Водночас проблеми адаптації систем управління організацій з урахуванням людського чинника у разі формування управлінських проектних команд у сучасних умовах ще недостатньо досліджені.

\section{Постановка цілей}

Дослідження теоретичних основ і прикладних проблем адаптації систем менеджменту 3 урахуванням людського чинника зумовила потребу вирішення таких цілей:

- обгрунтувати теоретичні засади формування простору підготовки та вирішення управлінських рішень;

- розробити концепцію адаптації системи управління організації з урахуванням людського чинника.

\section{Виклад основного матеріалу}

Розвиток сучасної економіки ознаменував структурні зміни, за яких основною рушійною силою стали знання, а тому значно зросли вимоги до організування управлінської праці. Процеси глобалізації інформаційної сфери призвело до поява мережевих організаційних структур, що будуються на передачі більшої свободи підрозділам, порівняно з ієрархічною схемою традиційної 
економіки і підвищують мобільність персоналу при вирішенні бізнес-питань. Утворення моделей нового типу систем управління організацій характерне для усіх галузей і відповідає стратегічним вимогам, які виражаються, передусім, у необхідності гнучкого й інтегрованого обслуговування ринків.

В умовах глобальної трансформації ринкової економіки високоефективна адаптація конкурентоздатних механізмів управління організацій в Україні відбувається в складних соціальноекономічних умовах. Тут потрібно відзначити такі чинники. По-перше, це нестабільність економічних процесів, зокрема відсутність стабільного поступального розвитку і нагальні потреби оновлення продуктивних сил в умовах дефіциту ресурсів. По-друге, глобальна трансформація інформаційної інфраструктури інтенсифікує задіяння нових інформаційно-комунікаційних інструментів у сфері менеджменту. По-третє, гостра нестача висококваліфікованого менеджменту, який був би здатний задовольняти вимогам господарювання, що зумовлює неефективність економічної політики у вітчизняних організаціях.

Сучасна організація є складним організмом, який постійно розвивається, у якому поєднуються інтереси персоналу, обмеження і стимули, жорстка технологія виробничих процесів i органічне впровадження інновацій, безумовна дисципліна і вільна творчість, нормативні вимоги i неформальні ініціативи. Кожна організація сформувала власну організаційну культуру, традиції, імідж серед споживачів. Розроблені методи управління грунтуються на об'єктивних законах, які були сформовані за всю попередню історію в галузі, так і на основі набутого досвіду менеджерів організації. Водночас організації розвиваються під впливом зовнішнього середовища. Вони банкрутують, якщо нездатні виконувати свої зобов'язання. Успішні організації ефективно використовують знання економічної теорії, сформованої політики розвитку і способів практичної реалізації завдань. У підсумку сумарні зусилля спрямовують на досягнення найвищого результату за максимально знижених затрат праці та ресурсів.

Механізми організування систем управління в організаціях, які часто застосовуються, не задовольняють сучасні вимоги господарювання і на рівні невеликих організацій, і на рівні вищих ланок управління господарством. Насамперед це зумовлено динамічними змінами систем управління, які удосконалювалися у зв'язку з удосконаленням інструментів інформаційного забезпечення і глобалізації взаємодій. Зазначимо, що ефективність управління залежить не тільки від технічного прогресу, а все більше від рівня кваліфікації працівників, а також від їхнього спрямування на вирішення завдань організації. Відповідно, ефективний управлінець повинен керуватися не тільки економічними знаннями, а дотримуватись політики організування діяльності організації, володіти засобами управління на практиці.

Узагальнюючи сказане, можна стверджувати, що менеджмент організацій базується на трьох базових концептуальних опорах, які стосуються:

- застосування економічних теорій, науково-економічних методів для планування діяльності організації;

- адаптування і сумісного дотримання політики організації для мотивування і організування діяльності організації;

- контролювання і регулювання діяльності організації на практиці.

Розгляньмо ці положення детальніше.

У сучасному світі проблеми, які вирішують менеджери, стають усе більш різнорідними, а їх вирішення вимагають врахування політичних, культурних і соціально-економічних чинників [8, 10]. Не розуміючи суті соціально-економічного розвитку організацій і закономірностей їхньому розвитку, не можна ні управляти організаціями, ні ефективно використовувати їхній потенціал, ні освоювати сучасні технології їхньої діяльності. Шлях наукового пошуку методів побудови раціональних організаційних структур лежить у площині перетину різних концепцій і теорій. Визначальною тенденцією розвитку наукових поглядів на принципи і закономірності функціонування організаційно-економічних систем, на механізми формування чинників конкурентоспроможності промислових підприємств $є$ широке застосування математичних методів і моделей для економічних досліджень. Інакше кажучи, управління виробництвом повинно спиратися на найновіші багато- 
планові, гуманітарні, насамперед, галузі знань, воно має бути науковим. Тут доцільно згадати, що ще Ф. Тейлор вважав менеджмент наукою, яка грунтується на фундаменті точних законів, правил, принципів, відокремлення планування від фактичного виконання роботи. Він також дотримувався думки, що управлінська діяльність вимагає певної фахової компетенції від менеджера. Очевидно, що коли кожен управлінець/фахівець зосередить свою увагу на тій ділянці роботи, яку він зможе виконати більш успішно, то організація загалом тільки виграє. Доцільно привести принципи кількісної школи менеджменту, у фундаментальну основу якої покладено ідею про те, що управління $\epsilon$ певним логічним процесом, який можна відобразити за допомогою формалізованих математичних моделей. Прийнято вважати, що математична модель допоможе відобразити проблему і шляхи іiі вирішення у вигляді основних іiі цілей та взаємозв'язків. Не випадково В. Баумоль зазначив, що “використання теоретичного й економетричного аналізу в прикладних цілях: для розробки макроекономічної політики, системи оподаткування, аналізу портфелів фінансових інструментів, при вирішенні суперечок по антистресових і інших економічних питань в судах і регулюючих інстанціях" є одним 3 найважливіших досягнень економічної науки XX ст. Моделювання є одним із найважливіших методів досліджень сучасної економічної науки. Математичні моделі ось уже майже два століття використовують для дослідження проблем регіонів, регіональних систем, просторової структури економік окремих територій, а також окремих аспектів діяльності суб' єктів господарювання. При застосуванні моделювання в разі підготовки і ухвалення управлінських рішень доцільне послідовне здійснення сукупності взаємопов'язаних етапів дослідження, які наведені на рис. 1.

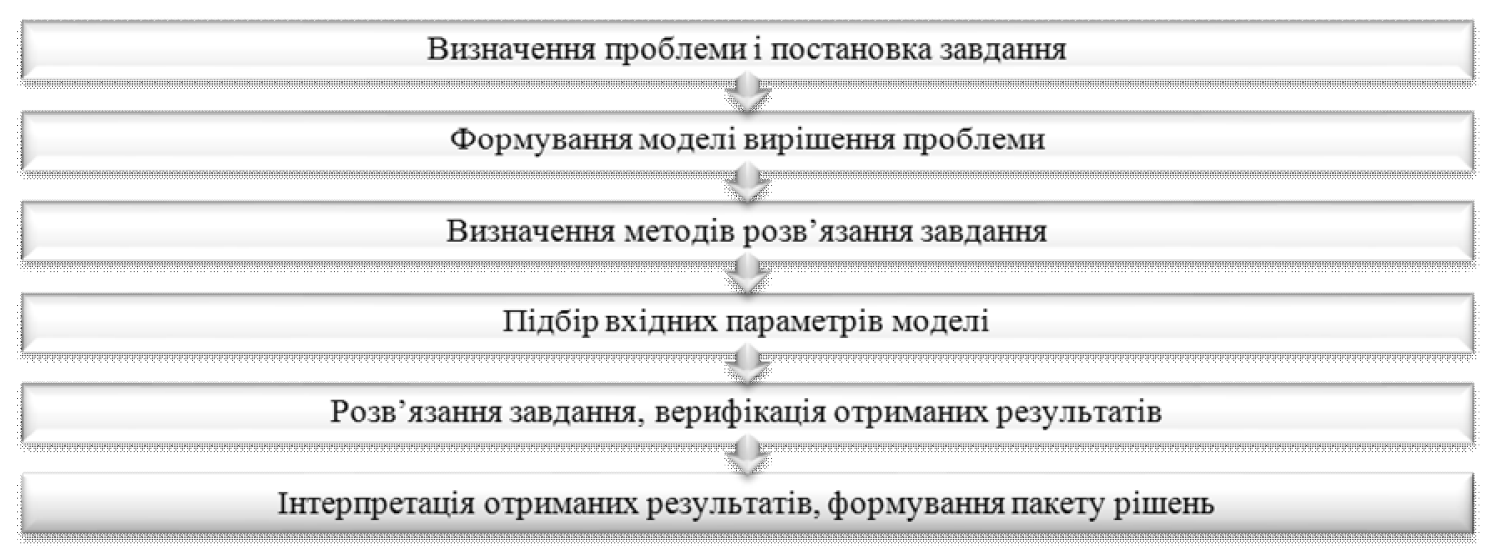

Рис. 1. Основні етапи прийняття рішень

* Розроблено авторами за [4, 7]

Зазначимо, що наукові підходи в менеджменті удосконалюються, водночас вони стали основою розвитку шкіл управління, які різняться одна від одної рівнем уваги до підсистем організації та об’єктів управління. Інтенсивний розвиток теорії і практики наукового менеджменту не міг не торкнутися управлінських процесів у виробництві та оптимального їхнього обгрунтування в українській науковій думці. Через суттєве ускладнення середовища прийняття управлінських рішень у рамках концепції наукового управління переконливо доведено, що для досягнення запланованої мети потрібні методи, що вже апробовані в природничих науках чи техніці і можуть бути ефективно використані в практиці діяльності організацій. Звичайно, слід врахувати, що в більшості випадків спрощення проблеми, яке потрібне для формалізованого представлення моделі, вимагає високого рівня підготовки фахівців. В іншому випадку, сліпе використання напрацьованих методів управління та інших умовах може привести до негативних результатів. Звідси випливає, що ідеальних “рецептів" на всі випадки життя розробити неможливо. Особливо важливо використовувати сучасні наукові методи, а також потенціал інформаційно-комунікаційних технологій. Для визначення найкращих способів досягнення мети й вирішення конкретних завдань потрібне використання наукового аналізу, а також забезпечення працівників інформаційними ресурсами, необхідними для ефективного організування виконання завдань. Ця увага спричинила в певних межах практичну значущість шкіл для окремого періоду розвитку господарського життя. 
Політика визначає напрям діяльності або місію організації, на основі якої розробляється стратегія, цілі діяльності, програми їх досягнення, визначення часткових цілей підрозділам i розподіл ресурсів. Загалом внутрішня політика відкриває конус можливостей для персоналу, чому працівники діють так, а не інакше. На ці запитання має дати відповідь внутрішня політика організації, і вона має опиратися як на узагальнення новітнього світового досвіду, так і враховувати менталітет поведінки вітчизняних організацій. У рамках обраної політики організація пояснює усім співробітникам і демонструє громадськості сенс діяльності і перспективи розвитку організації. Горизонт бачення, тобто період планування розвитку організації в часі, може бути різним: від кількох місяців до років. Стратегія менеджменту знаходить реальне втілення в програмі розвитку, меті і місії, принципах практичного управління, вимогах до персоналу, в методиках розробки управлінських рішень. Під стратегією можна розуміти сукупність орієнтирів і обмежень, які визначають напрям розвитку організації відповідно до поставленої мети. Стратегія - це своєрідний “коридор" використання різних тактик. Тактика - це мистецтво можливого в поточній реалізації стратегічного задуму. Тактика менеджменту - це сукупність управлінських рішень, що відбивають найкращий варіант реалізації стратегічних цілей у конкретних умовах функціонування організації. Ціль політики розвитку організації полягає в досягненні бажаного стану підприємства і з часом має корегуватися. Для корпорації таке представлення охоплює політичну, економічну, соціальну ситуацію в країні, в галузі, а також про бажаний стан організації. Для сприйняття і поширення основ політики серед персоналу основні положення політики потрібно представити у формі лаконічної, адаптивної конструкції, зручної для сприйняття (наприклад, девіз), яка заслуговує на довіру і містить орієнтири для розроблення стратегії чи тактики поведінки на період планування виробництва. Елементом політики підприємства є місія, яка деталізує статус підприємства i забезпечує орієнтири для вироблення цілей і стратегій на різних організаційних рівнях на основі реального стану організації. Це завдання загострюється, адже широке і повсюдне поширення високих технологій відкрило доступ до величезних обсягів інформації. Потік даних, які обробляє система управління організації, постійно зростає. Але що більше інформації збирається, то складніше побачити в ній тенденції і закономірності, приховані від поверхневого погляду, щоб прийняти на іï основі яке-небудь управлінське рішення. Украй важливо в цих умовах швидко i своєчасно знаходити корисну інформацію та ефективно іiі використовувати. У бізнесі взагалі інформація повинна відіграти ключову роль: без чіткого розуміння свого місця на ринку, потреб клієнтів, дій конкурентів - неможливо побудувати ефективну організацію. Підприємницька діяльність пов'язана 3 постійним пошуком найвигіднішого варіанта розподілу різного виду ресурсів: фінансових, трудових, товарних, технічних тощо.

Тут доцільно застосувати ситуаційний підхід, його придатність підтверджується практикою, адже не існує єдиного кращого способу керувати організацією з урахуванням безлічі збурювальних чинників і у самій організації, і в навколишньому середовищі. Проте не можна забувати про те, що кожен керівник при вирішенні виробничих завдань, при виборі стратегії і тактики управління передусім спирається на свій індивідуальний досвід і на суб'єктивні уявлення про методи вирішення цих завдань. Сучасні економічної теорії недостатньо повно враховують стан реальної вітчизняної господарської практики, а особи, що приймають рішення, нехтують відмінністю між нормативним і реальним господарським механізмом. У осяжному майбутньому потужний аналітичний апарат і засоби комп’ютерної обробки інформації залишаться в ролі дорадчих засобів в процесі ухвалення управлінського рішення, яке у багатьох відношеннях ближче до мистецтва і залежить від таланту і досвіду керівника. Від того, наскільки адекватно вони відображені в практичній діяльності організації, залежать і результати діяльності організацій.

Сучасна господарська практика має бути результатом вибору правильних тактичних i стратегічних рішень, правильно побудованої економічної політики, це дасть змогу переламати тенденцію “хотіли як краще, а вийшло як завжди”. На практиці для підвищенні продуктивності праці, розширення обсягів виробництва необхідне систематичне використання функцій контролювання i регулювання. Дехто вважає, що менеджером може бути лише той, хто має талант організатора, вміє розвивати цей талант і користуватись ним заради розвитку суспільства. 
Управлінське рішення - результат аналізу, виконаного на основі дослідження ситуації, прогнозування і вибору оптимального варіанту, розробка конкретного плану заходів, спрямованих на досягнення поставленої мети. Основний зміст управлінського рішення визначається метою управлінської дії. Окрім основної, генеральної мети, існує і сукупність часткових цілей, без здійснення яких досягнення генеральної мети не може бути досягнуте. Нерідко випадки, коли ці локальні цілі вступають між собою і протиріччям, тобто досягнення однієї мети може завдати збитків іншій. Володіння основами сучасного менеджменту - важкий, багатоплановий процес, який оцінюють фахівці з різних боків. Реальна економічна ситуація виникла тому, що господарські і політичні керівники недостатньо (через незнання або небажання) опиралися на економічну теорію.

Наведені пояснення лежать у площині зв'язків між елементами тріади теорія - політика практика. Очевидно, цілісність і стабільність розвитку економіки визначає наявність надійних $\mathrm{i}$ ефективних каналів зв'язку між вершинами тріади, а також сприйнятливості іiі елементів до інформації, що надходить через ці канали.

Простежуючи аргументацію і динаміку економічних оцінок, можна помітити, що застосування одного 3 перерахованих пояснень не завжди об'єктивно обгрунтоване. Часто це зумовлено суб' єктивними чинниками, які характеризують ставлення фахівця до важливості трьох основних складових економічного життя: теорії, політики і практики [9]. Така класифікація $\epsilon$ корисною для аналізу інтерпретації результатів досліджень. Кожен суб'єкт інтуїтивно применшує чи підвищує роль певного компонента тріади "економічна теорія - економічна політика - господарська практика”. Іноді такі підходи об’єктивно зумовлені і відображають реальну слабкість взаємозв' язків, хоча дещо суб'єктивно. Бажано збалансувати застосування економічної теорії, господарських рішень i реальної економічної практики, які утворять цілісну систему, що перебуває у діалектичній єдності, елементи якої взаємно збагачують, направляють і підтримують один одного.

На рис. 2 представлено класифікацію таких психологічних типів у галузі економіки, що відображає їхнє уявлення про роль і значущість складових тріади.

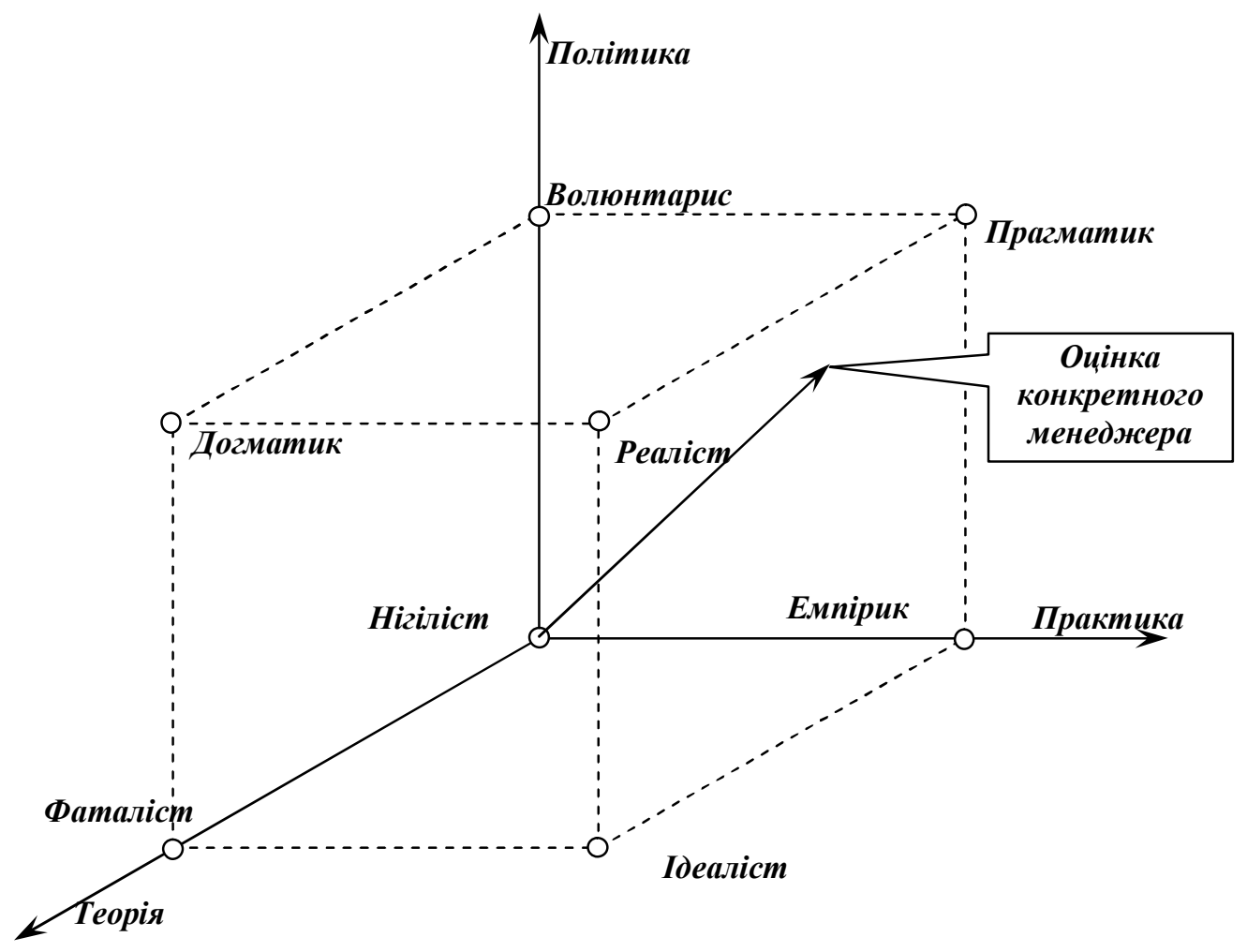

Рис. 2. Аналіз ймовірної поведінки економіста *авторська розробка 
Зазвичай наведені типологічні типи фахівців є абстрактними і на практиці трапляються рідко. Наведемо нижче коротку характеристику економістів-дослідників:

- економіст-фаталіст вірить у силу і невідворотність дії економічної теорії незалежно від реальної економічної політики і практичної ситуації;

- економіст-волюнтарист вважає результати теорії незначимими, проте вважає, що ухвалення певних управлінських рішень змінить економічну ситуацію в потрібному напрямі;

- економіст-догматик визнає значущість економічної теорії і переконаний, що спланований результат буде досягнуто, якщо економічна політика задовольняє цю теорію;

- економіст-ідеаліст не сумнівається в економічній теорії і в тому, що вона інспірована практичним досвідом, а тому адекватно пояснює економічну реальність;

- економіст-прагматик визнає дієвість економічної політики, що грунтується на фактах, але ігнорує теоретичні дослідження;

- економіст-емпірик віддає пріоритет фактам реальної економіки і вважає економічну практику самодостатньою, яка розвивається за внутрішніми законами, пізнання яких надто ускладнене або неможливе;

- економіст-реаліст визнає значимість усіх вказаних компонентів тріади, які перебувають у складній взаємодії і обліковуються в усіх видах дослідницької або практичної економічної діяльності;

- нігіліста важко назвати економістом, оскільки він відхиляе значення теорії, практики і політики.

Значущість інформації в тріаді “економічна теорія - економічна політика - господарська практика" по-різному сприймає кожний дослідник, причому співвідношення між значущістю цих компонентів для кожного індивіда має стійкий характер. Останнє дає змогу розділити індивідів на групи, що відповідають різним психологічних типом особи. Звичайно, кожному менеджерові можна поставити у відповідність певний вектор у тривимірному просторі 3 координатами $\stackrel{\prime}{X}\left(x_{1} ; x_{2} ; x_{3}\right)$, де $0 \leq x_{1} ; x_{2} ; x_{3} \leq 1$. Цей вектор можна отримати в результаті експертного оцінювання можливостей працівника.

Сучасні тенденції спрощення і зменшення структурного й функціонального складу органів системи управління організацій актуалізують завдання оптимізації організаційних форм і методів колективного управління. У загальному розумінні такий підхід заснований на формуванні команди, яка об'єднана однією метою і завданнями, здатна досягати мети автономно і злагоджено за мінімальних управлінських впливів.

Тому вдосконалення роботи системи управління організацій нерозривно пов'язане 3 командним підходом до формування колективу виконавців 3 урахуванням їхніх типологічних характеристик. Основним інтегруючим чинником створення і організування діяльності такої команди $є$ досягнення певної стратегічної мети. Первинною умовою формування такого колективу $\epsilon$ визначення кола функціональних завдань, інтенсивності їх виникнення тощо. За правило перед управлінською командою ставлять сукупність типових завдань, які вимагають у різній мірі використання знань і навиків у сферах теорії, політики і практики. У типовому випадку кожному менеджеру можна поставити певний конус функцій $S(0 ; \dot{a} ; \angle \alpha)$, приклад якого наведено на рис. 3 .

Загалом завдання укомплектування колективу управлінців можна звести до задачі математичного програмування:

$$
\begin{gathered}
\sum_{i=1}^{n} \lambda_{i} \rightarrow \min , * \\
\Omega_{\Sigma}\left(0 ; a_{\Sigma} ; \alpha_{\Sigma}\right) \subset \bigcup_{i=1}^{n}\left(\Omega_{i}\left(0 ; a_{i} ; \alpha_{i}\right) \times \lambda_{i}\right)
\end{gathered}
$$

*Авторська розробка.

де $\Omega_{\Sigma}\left(0 ; \mathfrak{a}_{\Sigma} ; \alpha_{\Sigma}\right)$ - сукупний конус функціональних завдань; $\Omega_{i}\left(0 ; \mathfrak{a}_{i} ; \alpha_{i}\right)$ - персоніфікований конус функціональних можливостей і-го фахівця; $\lambda_{i}$ - бінарна змінна, що набуває значення 1 , коли менеджер залучений до колективу і 0 - коли не залучений, $\mathrm{n}$ - кількість менеджерів-претендентів на участь у проектній команді, $\stackrel{1}{a}_{i}$ - вектор найхарактерніших ознак діяльності і-ого менеджера. 


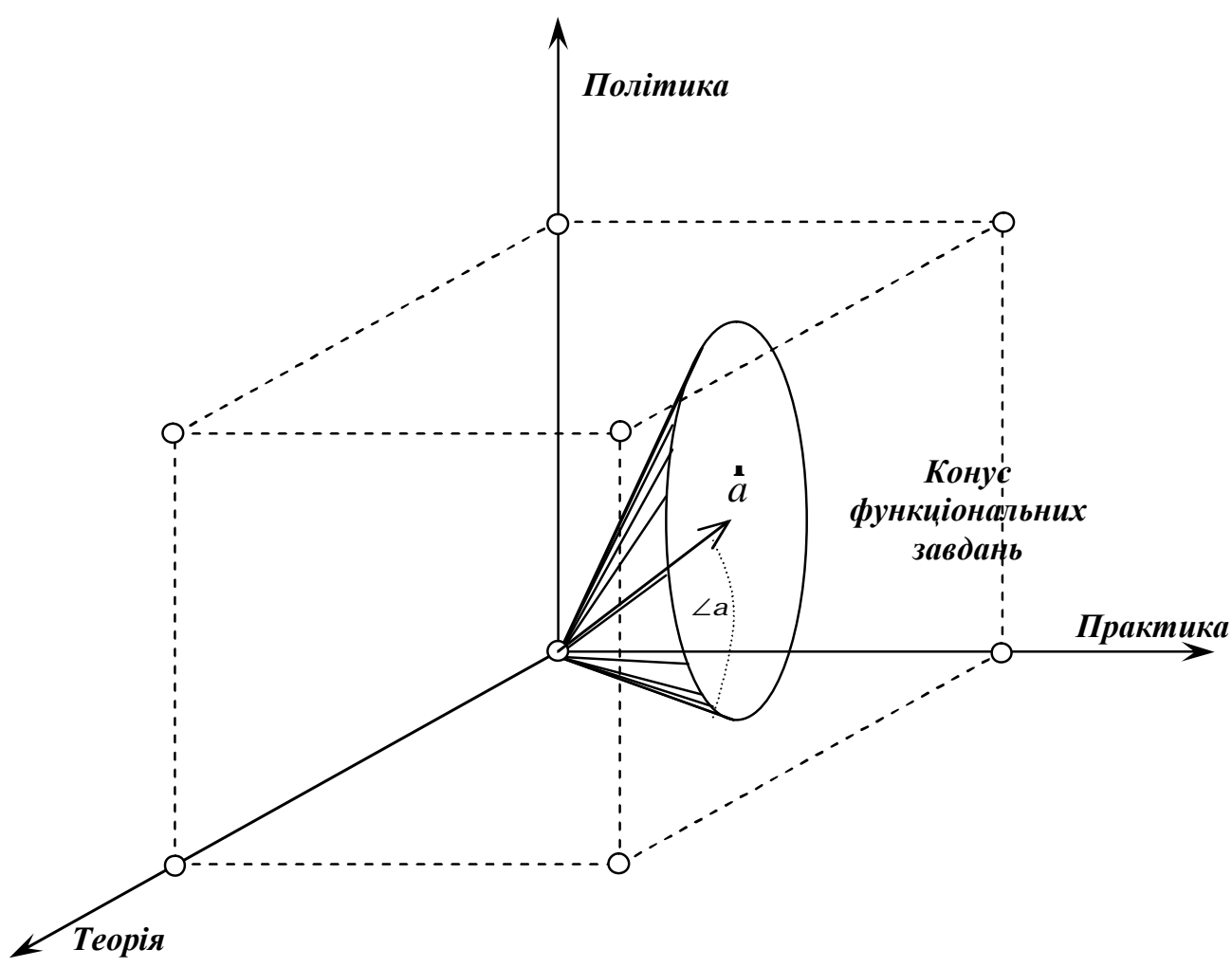

Рис. 3. Конус функиіональних завдань для досягнення реалізації мети діяльності організації *Авторська розробка

Суть цього завдання полягає в мінімізації необхідних фахівців для виконання заданого кола узагальнених функціональних завдань для досягнення певної мети діяльності організації [7, 9].

Такий підхід ефективний у разі створення професіональної команди для нового проекту. За формою команда проекту відображає бажану організаційну структуру управління проектом, розділення функцій, обов'язків і відповідальності за рішення в процесі його реалізації. За змістом команда проекту є групою висококваліфікованих фахівців, що володіють знаннями і навичками, необхідними для ефективного досягнення цілей проекту. Процес формування команди проекту звичайно розглядають як утворення єдиного, цілісного колективу управлінців для реалізації політики організації. Слід зазначити, що новизна, унікальність, ризик і швидкоплинність -усі ці риси притаманні новому проекту, вони ж і визначають труднощі при формуванні команди.

\section{Висновки}

У сучасних умовах ефективне управління насамперед означає формування колективу менеджерів, здатних згенерувати сукупність цілеспрямованих дій з метою реалізації проектів чи комплексу завдань у часі під впливом зовнішнього середовища. Ефективний результат управлінської діяльності досягається виключно за умови правильного, розумного, наукового залучення колективу фахівців з метою погодження їхніх дій і підтримання стану впорядкованості, плановості та динамічної рівноваги з зовнішнім середовищем. На основі тісної і чіткої взаємодії між членами управлінської команди для впливу на активне середовище організації формується активне самоорганізаційне поле прийняття управлінських рішень.

Розроблення концептуальних засад для оцінювання ефективності діяльності менеджерів у системі управління організації з урахуванням типологічного чинника характеристик фахівців дає змогу розробити концепцію управління з урахуванням інноваційних змін в умовах становлення мережевої економіки. Такий підхід з урахуванням типологічних характеристик задіяних фахівців дозволяє компетентно і вчасно управляти досягненням важливих завдань для організації.

\section{Перспективи подальших досліджень}

Наведені підходи щодо формування управлінської команди в організації з урахуванням типологічних характеристик менеджерів-претендентів потребує розроблення механізмів реалізації 
запропонованих методів на практиці. Очевидно, що узгодження загальної моделі формування управлінських команд потрібно проводити на різних рівнях функціонального наповнення і ступенів деталізації організування діяльності. Насамперед це стосується розроблення й адаптування експертних методів оцінювання ефективності використання наявного управлінського потенціалу організації і ефективності його використання.

1. Акофф Р. (1985) Планирование будущего корпорации; пер. с англ. - М.: Прогресс, 326 с. 2. Белл Д. (1999) Грядущее постиндустриальное общество. Опыт социального прогнозирования. Д. Белл; пер. с англ. под ред. В. Л. Иноземцева. - М., 783 с. 3. Клейнер Г. Б. (2001) Экономикоматематическое моделирование и экономическая теория, Экономика и математические методы. № 3. Т. 37. 1-25. 4. Кузьмін О. С., Яцура В. В., Грибик I. І., Грищук А. М., Смолінська Н. В. (2014) Управління змінами, Львів: Вид-во Львівської політехніки», 356 с . 5. Тімофєєва В. О., Чумаченко І. В. (2015) Моделювання процесів в економіці та управлінні проектами 3 використанням нових інформаційних технологій : монографія, Х.: ХНУРЭ, 244 с. 6. Морушко О. О., Висоцький А. Л. (2016) Основні управлінські культури: соціонічний аналіз, Теоретичні та практичні аспекти економіки та інтелектуальної власності. - Вип. 1 (13). - Т. 1. - Маріуполь. 55-61. 7. Новаківський I. І. (2016) Система управління підприємством в умовах становлення інформаційного суспільства: монографія, Львів: Видавництво Львівської політехніки, 316 с. 8. Процак К. В., Романів Л. В. (2016) Психологічні аспекти адаптації персоналу організації, Вісник «Проблеми економіки та управління», Львів: Видавництво Львівської політехніки, № 847. 238-243. 9. Тоффлер О. (1999) Адаптивная корпорация, Новая постиндустриальная волна на Западе. Антология под ред. В. Т. Иноземцева. - М.: Академия. 448-464. 10. Чухрай Н. І., Просович О. П. (2015) Стратегічне управління інноваційним розвитком підприємства: підручник, Львів: Видавництво Львівської політехніки, 500 с.

1. Akoff R. (1985) Planirovanie budushchego korporatcii [Planning for the Future of Corporation].Moskva: Progress. 2. Bell D. (1999) Griadushchee postindustrialnoe obshchestvo. Opyt sotcialnogo prognozirovaniia. [The coming post-industrial society. Experience of social forecasting] Moskva: Academia. 3. Kleiner G. B. (2001) Ekonomiko-matematicheskoe modelirovanie i ekonomicheskaia teoriia [Economic-mathematical modeling and economic theory]. Ekonomika i matematicheskie metody[Economics and Mathematical Methods], 3(37), 1-25. 4. Kuzmin O. Ye., Yatsura V. V., Hrybyk I. I., Hryshchuk A. M., Smolinska N. V. (2014) Upravlinnia zminamy [Change management]. Lviv: Vyd-vo Lvivskoi politekhniky. 5. Timofieieva V. O., Chumachenko I. V. (2015) Modeliuvannia protsesiv $\mathrm{v}$ ekonomitsi ta upravlinni proektamy $\mathrm{z}$ vykorystanniam novykh informatsiinykh tekhnolohii: monohrafiia [Model-making processes in economic projects and management projects with new technologies: monographs]. Kharkiv: KhNURE. 6. Morushko O. O., Vysotskyi A. L. (2016) Osnovni upravlinski kultury: sotsionichnyi analiz [Basic Controls of Cultures: Social Analysis]. Teoretychni ta praktychni aspekty ekonomiky ta intelektualnoi vlasnosti [Theoretical and Practical Aspects of Economics and Interactive Vlasnost], 1(13), 55-61. 7. Novakivskyi I.I. (2016) Systema upravlinnia pidpryiemstvom v umovakh stanovlennia informatsiinoho suspilstva: monohrafiia [Management System of the Enterprise in the Minds of the Establishment of information: monograph]. Lviv: Vydavnytstvo Lvivskoi politekhniky. 8. Protsak K. V., Romaniv L. V. (2016) Psykholohichni aspekty adaptatsii personalu orhanizatsii [Psychological aspects and adaptations to personnel of the organ]. Visnyk Problemy ekonomiky ta upravlinnia [Bulletin of Problems of economics and management], Vydavnytstvo Lvivskoi politekhniky, 847, 238-243. 9. Toffler O. (1999) Adaptivnaia korporatciia. Novaia postindustrialnaia volna na Zapade [New post-industrial wave in the West. Anthology]. Moskva: Akademiia, 448-464. 10. Chukhrai N. I., Prosovych O. P. (2015) Stratehichne upravlinnia innovatsiinym rozvytkom pidpryiemstva: pidruchnyk [Strategic management of innovative development of enterprise: manual]. Lviv: Vydavnytstvo Lvivskoi politekhniky. 


\section{MICT}

\section{ПРОБЛЕМИ ЕКОНОМІКИ}

Петрович Й. М., Бондаренко Ю. Г., Просович О. П. Інституційне середовище як важлива передумова розвитку рекреаційно-туристичної сфери

Блинда Ю. О., Прокопишин-Рашкевич Л. М., Демків Я. В., Васелевскі М.

Implementation of anti-crises investment strategies: machine-building case 16

Карий O. I., Проиак К. В. Маркетингові інструменти забезпечення якості надання адміністративних послуг.

Карковська В. Я., Хомин Р. М., Якимещь М. М., Судомир Н. Ю. Причини впливу кризових ситуацій на діяльність підприємств.

Кулініч T. В., Жайворонок I. Р. Аналізування фондових індексів,

як основних показників розвитку ринку цінних паперів окремих економік світу ..................... 44

Синютка Н. Г., Курило О. Б. Державні видатки в епоху цифрових технологій ............................... 51

Шеремета Б. О. Аналіз кінопрокатного ринку України та напрями його розвитку .......................... 57

Шкварчук Л. О., Слав'юк Р. А. Внутрішньокорпоративні фінансові потоки у системі управління підприємством.

\section{ПРОБЛЕМИ УПРАВЛІННЯ}

Петрович Й. М., Трут О. О. Моніторинг індивідуальної результативності працівників у процесі управління організацією

Данилків Х. П., Гавран В. Я., Гавран М. І., Грондскі Р. Управління фінансами підприємств оптової та роздрібної торгівлі.

Двуліт 3. П., Завербний А. С., Тиліпська Р. Б. Управління людськими ресурсами на основі ключових показників ефективності (KPI)

Лісовська Л. С., Теребух А. А., Гаиук М. М. Обгрунтування сучасних моделей та системи підтримки організаційної творчості

Новаківський I. І., .Висоцький А. Л. Формування проектної команди з урахуванням типологічних характеристик менеджерів 